\title{
PENGEMBANGAN BUKU SEKOLAH ELEKTRONIK INTERAKTIF BERBASIS LCDS PADA MATERI TEORI RELATIVITAS KHUSUS SEBAGAI BAHAN AJAR MANDIRI UNTUK MENUMBUHKAN KEMAMPUAN BERPIKIR KRITIS PADA SISWA
}

\author{
Mahkota*, Agus Suyatna, Eko Suyanto, I Dewa Putu Nyeneng \\ FKIP Universitas Lampung, Jl. Prof. Dr. Soemantri Brojonegoro No. 1 \\ *email: mahkota809@gmail.com
}

\begin{abstract}
Development of Interactive Electronic School Book Based on LCDS on Special Theory of Relativity as Self Instructional to Foster Student's Critical Thinking Ability. This research aimed to develop valid interactive electronic school book using LCDS on special theory of relativity as self instructional for foster student's critical thinking, to know readability and the ease of operating interactive electronic school book. The method used are research and development. The implementation of procedures adopted from Borg \& Gall design which consisted of 5 steps that were need assessment, developing preliminary form of product, expert validation, revision, and one-on-one test. Interactive electronic school book has been validated the material test with the score 3,31 (very appropriate) and the design test with the score 3,57 (very appropriate). Based on one-on-one test of interactive electronic school book shows the average score of the ease of operating aspect is 3,33 with very easy to operate as independent instructional and for readability aspect is 3,23 with very good quality.
\end{abstract}

Keyword: Interactive Electronic School Book, Self Intructional, Critical Thinking

\begin{abstract}
Abstrak: Pengembangan Buku Sekolah Elektronik Interaktif Berbasis LCDS Pada Materi Teori Relativitas Khusus Sebagai Bahan Ajar Mandiri Untuk Menumbuhkan Kemampuan Berpikir Kritis Pada Siswa. Penelitian bertujuan untuk mengembangkan Buku Sekolah Elektronik Interaktif berbasis LCDS pada materi teori relativitas khusus yang valid sebagai bahan ajar mandiri untuk menumbuhkan kemampuan berpikir kritis pada siswa serta mengetahui keterbacaan dan kemudahan dioperasikan. Metode penelitian yang digunakan adalah reseach and development atau penelitian pengembangan. Desain penelitian yang digunakan mengacu pada 5 tahapan Borg \& Gall yaitu analisis kebutuhan, pengembangan produk awal, validasi ahli, revisi dan uji satu lawan satu. Buku Sekolah Elektronik (BSE) interaktif ini telah tervalidasi uji materi dengan skor rata-rata 3,31 (sangat sesuai) dan validasi desain dengan memporeleh skor rata-rata 3,57 (sangat sesuai). Berdasarkan uji satu lawan satu BSE interaktif dapat diketahui bahwa pada aspek kemudahan dioperasikan mendapatkan skor rata-rata 3,33 dengan kualitas sangat mudah dioperasikan sebagai bahan ajar mandiri dan memiliki kualitas keterbacaan sangat baik dengan mendapatkan skor 3,23.
\end{abstract}

Kata Kunci: Buku Sekolah Elektronik Interaktif, Bahan Ajar Mandiri, Berpikir Kritis 


\section{PENDAHULUAN}

Pendidikan merupakan suatu proses yang digunakan setiap individu untuk mendapatkan pengetahuan, wawasan serta mengembangkan sikap dan keterampilan. Menurut UndangUndang Republik Indonesia Nomor 20 tahun 2003, pendidikan adalah usaha sadar dan terencana untuk mewujudkan suasana belajar dan proses pembelajaran agar peserta didik secara aktif mengembangkan potensi dirinya untuk memiliki kekuatan spiritual keagamaan, pengendalian diri, kepribadian, kecerdasan, akhlak mulia, serta keterampilan yang diperlukan dirinya, masyarakat, bangsa dan negara.

Pesatnya perkembangan dunia pendidikan memberikan tantangan bagi seorang guru untuk mengikuti perkembanganya. Seorang guru fisika harus pandai memilih bahan ajar dan teknologi yang tepat untuk membelajarkan Fisika. Fisika adalah salah satu pelajaran yang jarang diminati serta disukai oleh siswa kelas IPA. Berdasakan hasil observasi yang telah dilakukan di SMA

Berdasarkan analisis kebutuhan yang dilakukan pada salah satu SMA swasta di Bandarlampung diketahui bahwa 30 siswa kelas XII IPA semester genap, sebagian besar dari mereka masih mengalami kesulitan dalam pelajaran Fisika, hal ini disebabkan karena metode mengajar yang digunakan guru kurang sesuai.

Suatu proses pembelajaran Fisika mestinya selalu menggunakan dasar metode ilmiah. Suatu metode yang pada awalnya dimulai dengan fakta yang menarik perhatian sehingga memunculkan adanya masalah (Hasanah 2016). Dengan demikian halnya di dalam struktur pembelajaran Fisika, mestinya juga selalu diawali dengan fakta yang dialami oleh siswa dalam kehidupan sehari-hari, percobaan fisika, simulasi, media pandang dengar, model, gambar, dan buku.

Waktu yang ideal dibutuhkan oleh siswa untuk mempelajari semua materi pelajaran Fisika kelas XII semester genap sama dengan waktu siswa kelas $\mathrm{X}$ ataupun kelas XI menyelesaikan materi pembelajarannya, namun faktanya siswa kelas XII dituntut untuk menyelesaikan semua materi semester genap hanya dengan waktu 2 bulan 18 hari. Sehingga jelas bahwa waktu yang dibutuhkan siswa kelas XII lebih singkat dibandingkan siswa kelas $\mathrm{X}$ ataupun kelas XI, karena waktu yang dimiliki siswa lebih sedikit atau singkat maka siswa difokuskan sekedar untuk mengetahui materi yang penting atau biasa yang dikeluarkan di Ujian Nasional serta latihan soal. Akhirnya masalah yang timbul dari pelajaran sekilas adalah siswa tidak paham dengan konsep materi yang sesungguhnya.

Permasalahan waktu yang dimiliki oleh siswa kelas XII semester genap dapat diatasi dengan bahan ajar mandiri. Belajar mandiri merupakan suatu bentuk belajar yang memberikan keleluasaan pada siswa untuk dapat memilih atau menerapkan sendiri waktu dan cara belajarnya sesuai dengan ketentuan sistem kredit semester di sekolah (Rusman 2012). Belajar mandiri memiliki proses yang menekankan pada pembuatan inisiatif yang mandiri atau dengan bantuan orang lain untuk mengenali kebutuhan belajar mereka, memformulasikan tujuan belajar, mengidentifikasi bahan yang dibutuhkan untuk belajar, memilih dan mengimplementasikan strategi belajar, serta mengevaluasi hasil dari proses belajar (Anwar 2014). Wafroturrohmah dan Suyatmini (2013) menyatakan belajar mandiri sebagai suatu bagian dari kepribadian individu yang mampu dan mau untuk belajar sendiri, dengan 
atau tanpa bantuan pihak lain, dalam hal penentuan tujuan belajar, menentukan metode belajar dan evaluasi hasil belajar. Berdasarkan beberapa definisi dari belajar mandiri, maka dapat disimpulkan bahwa belajar mandiri adalah suatu bentuk belajar yang dilakukan sendiri tanpa tuntunan dari orang lain sebagai pengajarnya, dimana seseorang yang belajar mandiri dapat lebih leluasa untuk memilih waktu dan metode belajar yang tepat sesuai dengan kebutuhannya.

Bahan ajar mandiri ini dapat berupa buku sekolah elektronik. BSE adalah versi digital dari buku yang umumnya terdiri dari kumpulan kertas yang berisi teks atau gambar. BSE sendiri mejadikan teks dan gambar tersebut dalam informasi digital baik dalam format teks polos, *pdf, *jpeg, *lit, dan *html sehingga tampilan BSE bersifat statis (Yusmiari 2017). Buku Sekolah Elektronik (BSE) merupakan salah satu buku ajar yang kini banyak digunakan di berbagai sekolah Indonesia (Indhaka, dkk 2016). Media BSE adalah sumber belajar berupa file yang dapat diunduh melalui internet/buku cetak yang berlebelkan BSE (Sutrisno 2013). Sehingga dapat disimpulkan bahwa Buku Sekolah Elektronik (BSE) adalah salah satu buku ajar elektronik atau digital dalam bentuk format *pdf, *lit, *html, dan lain-lain. Buku sekolah elektronik ini terdapat dua jenis yaitu BSE dan BSE interaktif. Keunggulan dari BSE interaktif yaitu terdapat animasi, simulasi dan video pembelajaran yang dapat mem-permudah siswa memahami materi yang tergolong abstrak.

Menurut observasi yang dilakukan dapat diketahui salah satu materi yang sulit dipelajari adalah teori relativitas khusus dikarenakan materi ini tergolong materi yang abstrak. Sesuai dengan Widyanirmala, dkk (2014) yang me- nyatakan bahwa materi teori relativitas khusus siswa sulit mem-bangun konsep yang ada, karena materi ini, bersifat abstrak dan berbeda dengan fisika klasik yang sebelumnya dipelajari. Sehingga dalam mempelajari materi ini diperlukan media BSE interaktif yang dapat memberikan gambaran dengan jelas dikarenakan di dalam BSE interaktif dapat memuat simulasi percobaan.

Pembelajaran yang ideal juga menghadapkan siswa langsung pada kenyataan, dengan begitu siswa dapat memberikan inisiatif mereka untuk bertanya ataupun menjawab secara mandiri. Siswa juga dapat menemukan konsep materi yang diajarkan melalui penyelidikan atau penelaahan lebih lanjut, sehinga dapat menciptakan suatu pembelajaran yang bermakna. Pembelajaran yang bermakna dapat terjadi dengan mengajak siswa ikut serta secara langsung dalam memecahkan masalah yang ada sehingga muncullah keterampilan berpikir kritis pada siswa.

Syahbana (2012) mengemukakan bahwa berpikir kritis merupakan suatu cara berpikir yang menguji, menghubungkan, dan mengevaluasi semua aspek dari suatu situasi masalah, termasuk di dalamnya kemampuan untuk mengumpulkan informasi, mengingat, menganalisis situasi, membaca serta memahami dan mengidentifikasi hal-hal yang diperlukan. Rosana (2014) menyatakan berpikir kritis adalah kemampuan berpendapat dengan cara terorganisasi dan mengevaluasi secara sistematis bobot pendapat pribadi dari pendapat orang lain. Dwijananti \& Yulianti (2010) menyatakan berpikir kritis merupakan kegiatan menganalisis ide atau gagasan ke arah yang lebih spesifik, membedakan secara tajam, memilih, mengidentifikasi, mengkaji dan mengembangkannya ke arah yang lebih 
sempurna. Berdasarkan beberapa pengertian bepikir kritis menurut para ahli yang ada di atas, maka dapat disimpulkan bahwa berpikir kritis adalah keterampilan cara berpikir siswa dalam menanggapi suatu persoalan ataupun pertanyaan yang sedang dihadapinya.

Kemampuan berpikir kritis sangat penting dimiliki oleh siswa, mengingat bahwa saat ini sudah menggunakan Kurikulum 2013 dimana dalam Permendikbud No. 81 Tahun 2013 tentang implementasi kurikulum disebutkan bahwa kebutuhan kompetensi masa depan, dimana kemampuan peserta didik yang diperlukan yaitu kemampuan berkalaborasi, berkomunikasi, berpikir kreatif dan berpikir kritis (Kemendikbud 2013:10). Untuk memenuhi tuntutan kurikulum ini, maka perlu ditumbuhkan kemampuan berpikir kritis pada siswa agar proses pembelajaran dapat terlaksana dengan baik. Keterampilan berpikir kritis dapat dikembangkan pada siswa dengan menghadapkan siswa pada suatu isu persoaalan yang menuntut sikap kritis siswa untuk mempertanyakan dan meragukan suatu kebenaran melalui logika berpikir

Permasalahan yang ada serta untuk mengatasi tuntutan dari kurikulum 2013 maka perlu di-kembangkan Buku Sekolah Elektronik Interaktif berbasis LCDS pada materi Teori Relativitas sebagai bahan ajar mandiri untuk menumbuhkan kemampuan berpikir kritis pada siwa.

\section{METODE}

Metode penelitian ini adalah research and development atau penelitian pengembangan. Pengembangan yang dilakukan yaitu pengembangan media pembelajaran Buku Sekolah Elektronik Interaktif berbasis LCDS pada materi teori relativitas khusus sebagai bahan ajar mandiri untuk menumbuhkan berpikir kritis pada siswa.

Desain penelitian yang digunakan pada pengembangkan kali ini mengacu pada Borg \& Gall. Prosedur pengembangan Borg and Gall dibatasi 5 tahapan yaitu analisis kebutuhan, pengembangan produk awal, validasi ahli, revisi produk 1, dan uji satu lawan satu.

Pengambilan data pada penelitian ini menggunakan metode observasi dan kuesioner berupa angket analisis kebutuhan, uji validasi yang terdiri dari uji ahli desain dan uji ahli materi, dan uji satu lawan satu. Angket analisis kebutuhan ini diberikan kepada 30 siswa kelas XII dan seorang guru Fisika salah satu SMA swasta di Bandarlampung yang digunakan untuk mengetahui permasalahan yang dihadapi siswa kelas XII semester genap.

Uji validasi dilakukan untuk mengetahui apakah desain dan materi yang tertuang dalam produk yang dikembangkan sudah sesuai dengan ketentuan-ketentuannya. Uji ahli desain dan materi ini dilakukan oleh dua orang dosen yang bergelar doktor dan lektor kepala serta tiga orang guru yang bersertifikat. Pada instrumen angket penilaian uji validasi ahli memiliki empat pilihan jawaban yang menyatakan persetujuan terhadap pernyataan yang diberikan yaitu "sangat sesuai", "sesuai", "kurang sesuai", dan "tidak sesuai" seperti pada tabel 1.

Uji satu lawan satu dilakukan untuk mengetahui tingkat kemudahan pengoperasian dan keterbacaan BSE interaktif berbasis LCDS pada materi teori relativitas khusus. Uji satu lawan satu ini dilakukan pada 6 orang siswa untuk uji coba menggunakan BSE interaktif. 
Tabel 1. Skor penilaian terhadap pilihan jawaban

\begin{tabular}{lll}
\hline Skor & Kriteria Uji Keterbacaan & $\begin{array}{l}\text { Kriteria Kemudahan } \\
\text { Mengoperasikan BSE } \\
\text { Interaktif }\end{array}$ \\
\hline 4 & Sangat baik & Sangat mudah \\
3 & Baik & Mudah \\
2 & Kurang baik & Kurang mudah \\
1 & Tidak baik & Tidak mudah \\
\hline
\end{tabular}

\section{HASIL DAN PEMBAHASAN}

\section{Pengembangan BSE interaktif}

1. Hasil Analisis Kebutuhan

Pada tahap analisis kebutuhan dilakukan untuk mengumpulkan informasi dengan membandingkan kondisi sebenarnya dengan kondisi ideal yang seharusnya terjadi sejauh mana diperlukannya BSE interaktif. Analisis kebutuhan dilakukan dengan cara observasi dan angket analisis kebutuhan yang diberikan kepada guru dan siswa di salah satu SMA Swasta di Bandarlampung.

Hasil yang diperoleh dari kegiatan observasi dan kuisioner berupa angket menunjukkan bahwa sangat diperlukan sebuah alternatif bahan ajar mandiri berupa BSE interaktif untuk mengatasi permasalah waktu yang dimiliki oleh siswa kelas XII kelas IPA tidak banyak untuk mempelajari materi semester genap khususnya materi teori relativitas khusus yang tergolong materi yang abstrak sehingga sulit untuk dipahami. Berdasarkan hasil analisis kebutuhan guru dan siswa dapat diketahui bahwa materi teori relativitas tergolong materi yang abstrak dan sulit untuk dipelajari oleh siswa serta diajarkan oleh guru.

\section{Produk Awal}

Langkah yang paling awal dalam mengembangkan produk adalah melakukan uji ahli komponen materi. Uji ahli komponen materi ini dilakukan untuk mengetahui materi apa saja yang harus dituangkan dalam produk. Uji ini dilakukan oleh 3 orang dosen yang ahli dalam bidang materi teori relativitas khusus melalui angket uji ahli komponen.

Berdasarkan analisis uji ahli komponen materi diketahui bahwa komponen materi yang perlu dituangkan dalam produk ini adalah materi definisi kejadian, pengamatan, dan kerangka acuan, gerak relatif, transformasi Galileo, percobaan Michelson-Morley, postulat Einsten, transformasi Lorentz, dilatasi waktu, paradoks kembar, kontraksi panjang, massa relativistik, momentum relativistik, dan energi kinetik.

Langkah selanjutnya, menyusun naskah dan membuat produk sesuai dengan pemetaan materi. Materi-materi yang dituangkan dalam produk berasal dari sumber-sumber yang terpercaya dan telah teruji, materi tersusun dengan baik dan untuk mendukung pemahaman konsep terhadap materi yang disampaikan maka dituangkan animasi, simulasi dan video. Untuk memperkuat pemahaman siswa maka di dalam BSE I atau produk yang dikembangkan dituangkan pula contoh soal yang disertai dengan penyelesaiannya dibuat menggunakan macromedia flash 8 serta soal latihan interaktif dan evaluasi interaktif untuk mengukur sejauh mana akan pemahaman siswa akan materi teori relativitas khusus dibuat menggunakan Ispring QuizMaker.

Setelah semua komponen penyusun BSE interaktif lengkap, maka langkah selanjutnya adalah mengemas semua 
komponen menjadi satu. Program yang digunakan untuk mengembangkan produk berupa BSE interaktif ini yaitu Learning Content Development System (LCDS) 2,8, Microsoft power poin 2016, Macromedia Flash 8, Pinnacle 17, dan Ispring QuizMaker.

Learning Content Development System (LCDS) 2,8 merupakan aplikasi yang dapat membuat suatu produk dengan menggabungkan teks, animasi, simulasi, dan video. Hasil dari pengembangan produk pada tahap ini disebut sebagai produk I yang dapat dilihat pada gambar 1. Adapun desain pengembangan BSE interaktif dalam penilitian ini memiliki beberapa konten yaitu: (1) Pendahuluan yang terdiri dari cover, prakata, profil pengembang, kompetensi dasar, indikator, dan peta konsep. (2) Petunjuk BSE interaktif yang terdiri dari petunjuk penggunaan dan petunjuk belajar. Petunjuk penggunaan berisikan cara untuk mengoperasikan BSE interaktif beserta kegunaan tombol-tombol pada BSE interaktif. Sedangkan petunjuk belajar BSE interaktif berisikan penjelasan menu-menu yang ada pada BSE interaktif dan langkah-langkah dalam mempelajari BSE interaktif. (3) Tujuan pembelajaran pada setiap sub materi. (4) Materi yang berisikan gambar, animasi, simulasi, video, pertanyaan awal, pemaparan materi serta contoh soal, dan latihan interaktif. Serta (5) Penutup yang terdiri dari contoh real life, rangkuman, evaluasi interaktif, daftar rujukan, dan glosarium.

BSE interaktif pada materi teori relativitas khusus yang telah dikembangkan dapat digunakan secara mandiri. Pada BSE interaktif terdapat petunjuk penggunaan dan petunjuk belajar BSE interaktif. Adanya petunjuk penggunaan yang berisikan tata cara menggunakan atau mengoperasikan BSE interaktif dan petunjuk belajar BSE interaktif yang berisikan cara dalam mempelajari setiap langkah pada BSE interaktif memudahkan siswa dalam menggunakan BSE interaktif secara mandiri.

Penjelasan materi-materi teori relativitas khusus ini dilengkapi dengan penurunan rumus atau persamaan dan contoh soal yang dapat menumbuhkan rasa percaya diri siswa untuk mengerjakan soal-soal yang tersedia. Pada BSE interaktif ini terdapat juga soal latihan interaktif yang terbagi menjadi 3 latihan interaktif. Latihan interaktif 1 berisikan soal mengenai transformasi Galileo, percobaan Michelson-Morley dan postulat Einsten, latihan 2 berikan soal mengenai transformasi Lorentz, dilatasi waktu, paradoks kembar dan kontraksi panjang, serta latihan 3 berisikan soal mengenai massa relativistik, momentum relativistik dan energi kinetik. Soal latihan interaktif terdapat feedback sebagai reward yang diberikan terhadap jawaban yang dipilih oleh siswa. Pada bagian penutup terdapat rangkuman materi, evaluasi interaktif, daftar rujukan dan glosarium. Evaluasi interaktif pada BSE interaktif terdapat 10 soal interaktif yang memiliki feedback.

Dengan adanya animasi-animasi pada BSE interaktif seperti pada gambar 10 dapat mempermudah siswa memahami materi teori relativitas khusus yang merupakan materi abstrak. Hal ini sesuai dengan Suyatna, dkk (2017) yang menyatakan bahwa gambar bergerak berupa animasi maupun video dapat menjelaskan materi yang abstrak. Hal ini didukung oleh Isnawati dan Danang (2016) dan Anggraini, dkk (2017) yaitu dengan adanya video animasi sebagai sumber belajar akan mempermudahkan siswa dalam proses pembelajaran, khususnya dalam merealisasikan konsep materi yang bersifat 
abstrak. Hal ini juga sesuai dengan pernyataan Ryoo dan Lin (2014), dynamic visualization can use animated pictures to provide an explicit depiction of abstrak conseps and processes.

Dengan adanya simulasi percobaaan Michelson-Morley pada BSE interaktif dapat memudahkan siswa untuk melakukan percobaan dengan waktu yang singkat serta dapat mengatasi permasalahan sarana untuk melakukan percobaan karena alat yang digunakan untuk melakukan percobaan MichelsonMorley adalah interferometer. Hal ini sesuai dengan pernyataan Setiawan (2007) yaitu dalam pembelajaran fisika, simulasi praktikum diperlukan sebagai media untuk menggantikan pengamat atau percobaan yang tidak dapat dilakukan secara langsung, sebagai contoh praktikum efek fotolistrik. Pernyataan ini diperkuat oleh Cengiz (2010) yang menyatakan bahwa pengunaan laboratorium virtual (simulasi praktikum) dapat mengatasi beberapa masalah yang dihadapi terkait peralatan laboratorium yang kurang memadai dan memberikan kontribusi positif dalam mencapai tujuan pembelajaran.

Terdapat dua video yang pada BSE interaktif ini yaitu pengamat diam relatif terhadap objek diam dan pengamat bergerak relatif terhadap objek diam serta pengamat diam relatif terhadap objek bergerak. Melalui video yang terdapat pada BSE interaktif siswa diberikan pertanyaan mengenai video yang telah diamati yang dapat menumbuhkan kemampuan berpikir kritis siswa. Hal ini serupa dengan hasil penelitian Agustina, dkk (2017) yang menyatakan bahwa gambar bergerak sebagai media dalam kegiatan pembelajaran, memberikan kesempatan pada siswa untuk mengamati peristiwa yang lebih realistis karena gerakan gambarnya. Dengan menggunakan gambar bergerak, siswa dapat menganalisis, membuktikan dan menyimpulkan sendiri mengenai kejadian yang berkaitan dengan materi.

\section{Hasil Uji Validasi}

Produk 1 dikembangkan dalam bentuk html, selanjutnya dilakukan uji kelayakan yaitu uji desain dan uji materi. Uji ahli desain dilakukan untuk mengetahui apakah desain yang digunakan sudah tepat seperti pemilihan dalam combinasi warna, font, jenis huruf, kejelasan animasi dan simulasi serta kejelasan gambar yang dituangkan dalam BSE interaktif, untuk lebih rinci aspek apa saja yang dinilai pada uji ahli. Alat yang digunakan untuk uji ahli validasi ini berupa angket.

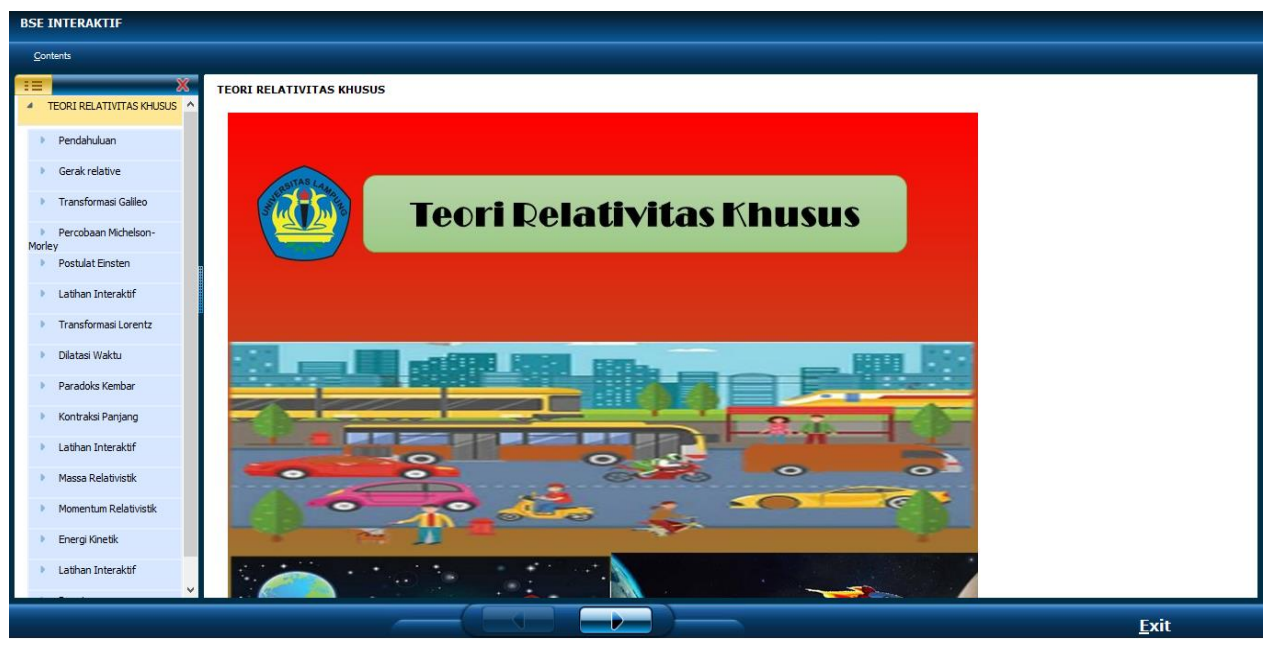

Gambar 1. Tampilan cover BSE interaktif menggunakan LCDS. 
Tabel 2. Hasil skor rata-rata uji ahli desain

\begin{tabular}{lll}
\hline Indikator & Skor rata-rata & Nilai kualitas \\
\hline $\begin{array}{l}\text { Layout design pada BSE Interaktif } \\
\text { pembelajaran }\end{array}$ & 3,57 & Sangat sesuai \\
$\begin{array}{l}\text { Typography dalam BSE Interaktif } \\
\text { pembelajaran }\end{array}$ & 3,53 & Sangat sesuai \\
$\begin{array}{l}\text { Ilustrasi dalam BSE Interaktif } \\
\text { pembelajaran }\end{array}$ & 3,55 & Sangat sesuai \\
BSE Interaktif untuk belajar mandiri & 3,51 & Sangat sesuai \\
\hline
\end{tabular}

Tabel 3. Hasil skor rata-rata uji ahli materi

\begin{tabular}{lll}
\hline Aspek & Skor rata-rata & Nilai kualitas \\
\hline Keakuratan materi & 3,44 & Sangat sesuai \\
Keakuratan tes interaktif & 3,20 & Sangat sesuai \\
Kemutakhiran materi & 3,33 & Sangat sesuai \\
$\begin{array}{l}\text { Kesesuaian materi dengan } \\
\text { penedekatan saintifik }\end{array}$ & 3,27 & Sangat sesuai \\
\hline
\end{tabular}

Uji ahli desain ini dilakukan oleh 2 validator yang bergelar doktor dan lektor kepala serta 3 guru fisika SMA kelas XII yang telah bersertifikat. Berdasarkan hasil skor rata-rata yang diperoleh pada uji ahli desain pada tabel 2 dapat dikatakan bahwa desain BSE interaktif yang telah dikembangkan sangat sesuai, namun terdapat saran perbaikan yaitu perlu dibuat petunjuk belajar dengan jelas.

Uji ahli materi dilakukan untuk mengetahui kelengkapan materi, kebenaran materi, sistematis materi dan berbagai hal berkaitan dengan materi seperti contoh-contoh, animasi, simulasi dan video pembelajaran serta pengembangan soal-soal latihan interaktif dan evaluasi interaktif. Alat yang digunakan untuk uji ahli materi dilakukan oleh orang yang sama dengan penguji desain.

Hasil skor rata-rata yang diperoleh pada uji ahli materi dapat dilihat pada tabel 3 dan dapat dikatakan bahwa materi dari BSE interaktif yang dikembangkan sangat baik namun terdapat beberapa saran perbaikan yaitu (1) Perlu dicek kembali KKO yang sesuai dengan online-learning, (2) Perlu menambahkan kata "mengamati animasi" dalam tujuan pembelajaran, (3) Perlu ditambahkan persamaan transformasi Galileo pada sumbu Y dan Z, (4) Perlu diganti umur pemeran pada animasi paradoks kembar, dan (5) Perlu ditambahkan contoh real life pada bidang teknologi.

Kedua uji validasi materi dan desain ini telah dilalui dan berdasarkan analisis kedua uji ini pada tabel 2 dan 3 dapat disimpulkan bahwa BSE interaktif yang dikembangkan memiliki desain yang sangat baik serta isi materi yang tertuang dalam BSE interaktif sangat baik, namun terdapat beberapa rekomendasi atau saran perbaikan seperti pada tabel 4. Berdasarkan hasil analisis uji desain dapat diketahui bahwa BSE interaktif yang dikembangkan dapat menumbuhkan kemampuan berpikir kritis diri pada siswa serta BSE interaktif ini dapat digunakan secara mandiri. Sehingga dapat dapat disimpulkan bahwa BSE interaktif berbasis LCDS pada materi teori relativitas khusus yang dikembangkan valid sebagai bahan ajar mandiri untuk menumbuhkan kemampuan berpikir kritis pada siswa sesuai dengan tujuan penelitian pengembangan ini. 


\section{Revisi}

Tahap selanjutnya melakukan revisi terhadap produk awal atau produk 1, yang direvisi yaitu saran perbaikan dari penguji dapat dilihat pada Tabel 4.

\section{Uji Satu Lawan Satu}

Uji satu lawan satu dilakukan dengan menggunakan angket untuk mengetahui keterbacaan dan kemudahan mengoperasikan BSE Interaktif. Tahapan ini menggunakan 6 orang siswa diberi perlakuan dengan memberikan pembelajaran materi teori relativitas khusus menggunakan hasil produk II dan dimintai pendapatnya tentang produk II ini.

Tabel 4. Rekomendasi perbaikan hasil uji ahli validasi

\begin{tabular}{|c|c|c|c|}
\hline No & Aspek Penilaian & $\begin{array}{c}\text { Rekomendasi } \\
\text { Perbaikan }\end{array}$ & $\begin{array}{l}\text { Tindakan } \\
\text { Perbaikan }\end{array}$ \\
\hline 1. & $\begin{array}{l}\text { BSE Interaktif memuat } \\
\text { petunjuk belajar yang } \\
\text { jelas, komunikatif, dan } \\
\text { mengandung kalimat } \\
\text { sapaan }\end{array}$ & $\begin{array}{l}\text { Buatlah petunjuk } \\
\text { belajar dengan jelas, } \\
\text { seperti dengan } \\
\text { memberi tahu } \\
\text { bagaimana siswa dapat } \\
\text { belajar menggunakan } \\
\text { BSE I }\end{array}$ & Telah diperbaiki \\
\hline 2. & $\begin{array}{l}\text { Kesesuaian tujuan } \\
\text { pembelajaran dalam BSE } \\
\text { Interaktif dengan } \\
\text { indikator pencapaian } \\
\text { kompetensi. }\end{array}$ & $\begin{array}{l}\text { Perlu menambahkan } \\
\text { kata "mengamati } \\
\text { animasi" dalam tujuan } \\
\text { pembelajaran }\end{array}$ & Telah diperbaiki \\
\hline 3. & $\begin{array}{l}\text { Kesesuaian materi yang } \\
\text { disajikan dalam BSE } \\
\text { Interaktif dengan } \\
\text { Kompetensi Inti (KI) dan } \\
\text { Kompetensi Dasar (KD). }\end{array}$ & $\begin{array}{l}\text { Perlu ditambahkan } \\
\text { persamaan transformasi } \\
\text { Galileo pada sumbu Y } \\
\text { dan Z. }\end{array}$ & Telah diperbaiki \\
\hline 4. & $\begin{array}{l}\text { Kesesuaian penggunaan } \\
\text { animasi dengan materi }\end{array}$ & $\begin{array}{l}\text { Perlu diganti umur } \\
\text { pemeran pada animasi } \\
\text { paradoks kembar. }\end{array}$ & Telah diperbaiki \\
\hline 5. & $\begin{array}{l}\text { Ketepatan penjelasan } \\
\text { konseptual materi }\end{array}$ & $\begin{array}{l}\text { Perlu ditambahkan } \\
\text { contoh real life pada } \\
\text { bidang teknologi. }\end{array}$ & Telah diperbaiki \\
\hline
\end{tabular}

Tabel 5. Hasil skor rata-rata uji satu lawan satu

\begin{tabular}{lll}
\hline Aspek & Skor rata-rata & Nilai kualitas \\
\hline $\begin{array}{l}\text { Keterbacaan BSE } \\
\text { interaktif }\end{array}$ & 3,23 & Sangat baik \\
$\begin{array}{l}\text { Kemudahan } \\
\text { penggunaan BSE } \\
\text { interaktif }\end{array}$ & 3,33 & Sangat mudah \\
\hline
\end{tabular}


Berdasarkan uji satu lawan satu menurut siswa BSE interaktif mudah digunakan karena dalam BSE interaktif ini terdapat petunjuk penggunaan dan petunjuk belajar sehingga siswa dapat menggunakan BSE interaktif secara mandiri tanpa arahan dari pengembang. Hal ini sesuai dengan hasil penelitian Wulandari, dkk (2016) yang mengemukakan bahwa modul interaktif yang dilengkapi petunjuk penggunakan memudahkan siswa untuk menggunakan modul dalam proses pembelajaran. BSE interaktif ini mempermudah siswa dalam memahami materi teori relativitas khusus dikarenakan BSE interaktif yang telah dikembangnya terdapat animasi, simulasi dan video pembelajaran. Selain itu, BSE interaktif yang dikembangkan memiliki keterbacaan yang baik, sehingga mempermudah siswa dalam memahami materi. Hal ini dapat terlihat dengan tidak adanya siswa yang mempertanyakan istilah-istilah atau kata-kata yang sulit dimengerti pada BSE interaktif dikarenakan bahasa yang digunakan bahasa indonesia yang mudah dimengerti serta terdapat glosarium pada BSE interaktif yang dikembangkan.

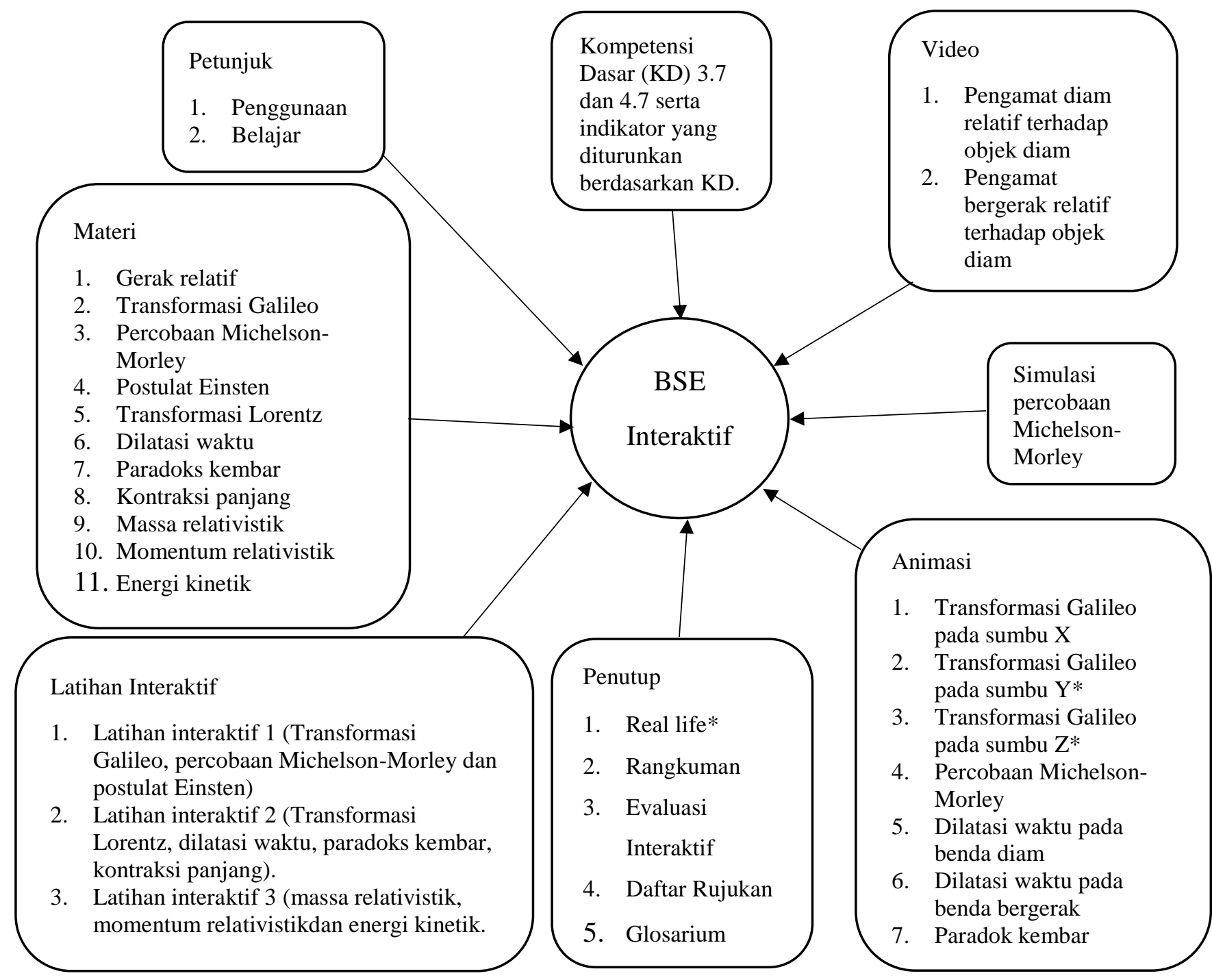

*: pengembangan dari produk 1

Gambar 2. Bagan hasil pengembangan produk 1 
Berdasarkan hasil analisis dari uji satu lawan satu pada tabel 5 dapat disimpulkan bahwa BSE interaktif yang dikembangkan memiliki keterbacaan yang sangat baik serta dapat digunakan dengan sangat mudah.

6. BSE Interaktif Materi Teori Relativitas Khusus Berdasarkan Hasil Validasi dan Uji Satu Lawan Satu

Hasil desain produk akhir atau final merupakan revisi perbaikan dan saran berdasarkan dengan hasil uji ahli validasi dan uji satu lawan satu seperti pada gambar 2.

Kelebihan dan Kekurangan dari BSE Interaktif yang Telah Dikembangkan

BSE interaktif yang dihasilkan memiliki beberapa kelebihan yaitu konsep mengenai teori relativitas khusus dapat divisualisasikan oleh komputer melalui ilustrasi animasi, gambar, simulasi, dan video pembelajaran, serta dapat dioperasikan pada laptop atau komputer manapun karena BSE interaktif ini di-publish dalam bentuk file berupa html. Selain memiliki kelebihan, BSE interaktif yang dihasilkan juga memiliki kekurangan yaitu video pembelajatan tidak akan dapat diputar sebelum pengguna menginstal terlebih dahulu Microsoft Silverlight dan memastikan mozila yang digunakan versi 35 atau 37. Software yang digunakan peneliti memiliki kukurang yaitu hanya memiliki satu jenis font serta belum memungkinkan untuk menambahkan persamaan teori relativitas khusus karena belum terdapat Microsoft Equation, maka untuk mengatasi kekurangan dari software ini peneliti memanfaatkan Microsoft Powerpoint 2016 lalu di simpan dengan format jpeg, jpg atau format lain yang mendukung.

\section{SIMPULAN DAN SARAN Simpulan}

Simpulan dari penelitian pengembangan yaitu pertama, dihasilkan BSE interaktif berbasis learning content development system (LCDS) yang telah tervalidasi sebagai bahan ajar mandiri untuk menumbuhkan kemampuan berpikir kritis pada siswa pada materi teori relativitas khusus berisi materi dalam bentuk teks, animasi, gambar, simulasi, video pembelajaran dan soal interaktif yang memanfaatkan aplikasi LCDS, I-Spring QuizMaker, Microsoft Power Point 2016, Macromedia Flash 8, dan Pinnacle 17 kemudian digabungkan menjadi buku sekolah elektronik (BSE) interaktif menggunakan software LCDS. Kedua, menurut siswa BSE interaktif yang dikembangkan mudah dioperasikan dengan skor yang diperoleh 3,33 atau dengan tingkat kualitas sangat mudah serta BSE interaktif memiliki keterbacaan yang baik dengan skor 3,23 atau dengan tingkat kualitas sangat baik.

\section{Saran}

Saran dari penelitian pengembangan ini yaitu pertama, bagi siswa buku sekolah elektronik (BSE) interaktif ini dapat dimanfaatkan karena dapat menumbuhkan kemampuan berpikir kritis pada siswa. Kedua bagi guru BSE interaktif ini dapat mengatasi keterbacaan waktu pertemuan (tatap muka) karena dapat dioperasikan secara mandiri tanpa kehilangan pendekatan saintifik.

\section{DAFTAR PUSTAKA}

Agustina, D., Suyatna, D., dan Suyanto, E. 2017. Perbandingan Hasil Belajar Siswa Menggunakan Media Gambar Bergerak Dengan Gambar Diam. Jurnal Pembelajaran Fisika, 5(3), 25-34

Anggraini, D., Suyatna, A., dan Sesunan, F. 2017. Studi Perbandingan Hasil Belajar Fisika 
Antara Penggunaan Gambar Bergerak dengan Gambar Statis. Jurnal Pembelajaran Fisika, 5 (1) 92-93.

Anwar, M. 2014. Peningkatan Intensitas

Belajar Mandiri Dengan Layanan

Informasi Di Kelas. Jurnal Universitas Muhammadiyah Yogyakarta, 1(2), 57-69

Cengiz, T. 2010. The Effect of the Virtual Laboratory on Students's Achievement and Attitude in Chemistry. Internasional Online Jurnal of Educational Sciences, 2 (1). 37-53.

Dwijananti, P., \& Yulianti, D. 2010. Pengembangan Kemampuan Berpikir Kritis Mahasiswa Melalui Pembelajaran Problem Based Indtruction Pada Mata Kuliah Fisika Lingkungan. Pendidikan Fisika Indonesia, 6, 108-114.

Hasanah, N., Winarto, H., dan Hartono, D. 2016 Pengembangan Media Pembelajaran Berbantuan Komputer pada Materi Elastisitas Untuk Siswa SMA Kelas X. Jurnal Fisika. 130-139

Indhaka, Willy Alif, Supraptono, Eko, dan Sugiarti, N. 2016. Penerapan Buku Sekolah Elektronik Berbasis Android Dalam Materi Ajar Besaran dan Satuan. Pendidikan Tindak Kelas, 17(2), 1-8.

Ismawati, D. A. dan Danang Tandyonomanu. 2016. Pengembangan Media Video Animasi Untuk Meningkatkan Hasil Belajar Siswa Dalam Pelajaran Matematika Sub Pokok Vahasa Hubungan Antar Sudut Kelas VII SMP Negeri 1 Krembung Sidoarjo. Jurnal mahasiswa teknologi pendidikan, 10 (1), 1-14.

Kemendikbud. 2013. Model Pengembangan Penilaian Hasil Belajar. Jakarta : Direktorat Pembinaan SMA.
Rosana, L. N. 2014. Pengaruh Metode Pembelajaran dan Kemampuan Berpikir Kritis Terhadap Hasil Belajar Sejarah Siswa. Pendidikan Sejarah, 3 (1), 34-44.

Rusman. 2012. Model-Model Pembelajaran. Jakarta: Raja Grafindo Persada.

Ryoo, K., \& Linn, M. C. 2014. Designing Visualizations. Journal of Research in Science Teaching, 51 (2), 147-174.

Setiawan, A., Suyatna, A., dan Abdurrahman. 2016. Pengembangan Simulasi Praktikum Efek Fotolistrik Dengan Pendekatan Inkuiri. Jurnal Pembelajaran Fisika, 4 (1), 47-56.

Sutrisno, Murtiono, A. . T. 2013. Alternatif Model Penggunaan Buku Sekolah Elektronik (BSE) Berbasis Project Learning Sebagai Salah Satu Sumber Belajar Di Sekolah Menengah Kejuruan. Jiptek, VI(2), 117-124.

Suyatna, A., Anggraini, D., Agustina, D., dan Widyastuti, D. 2017. The Rol of Visual Representation in Physics Learning: Dynamic Versus Statis Visualization. Journal of Physics Conferences Series, 909 (1), 1-7.

Syahbana, A. 2012. Pengembangan Perangkat Pembelajaran Berbasis Kontekstual Untuk Mengukur Kemampuan Berpikir Kritis Matematis Siswa SMP. Edumatica, 2 (2), 17-26.

Wafroturrohmah \& Suyatmini. 2013. Penggunaan Metode Problem Based Learning untuk Meningkatkan Kemampuan Belajar Mandiri Mahasiswa Jurusan Pendidikan Akutansi Pada Mata Kuliah Akutansi Perpajakan. Accounting Education Departement FKIPUMS. Jurnal Pendidikan Ilmu Sosial, 23 (1), 32-41. 
Widyanirmala, Asra, I M., Bakri, F., Gina A. I., Azizah, N., Nugraha, A., \& Rizki, R. P. 2014. Prosiding Seminar Nasional Fisika (EJurnal), 3, 62-66.

Wulandari, S. R., Suyanto, E., dan Suana, W. 2016. Modul Interaktif Dengan Learning Development System Materi Pokok Listrik
Statis. Jurnal Pembelajaran Fisika, 4 (2), 22-34.

Yusmiari, N. N., Agung, A. A. G., \& Suwatra, I. W. 2017. Pengembangan Buku Pintar Elektronik (BPE) Berbasis Pendekatan Ilmiah Pada Mata Pelajaran IPA Semester Genap. Jurnal Edutech Undiksha, 8(2), 1-13. 